\title{
Preliminary evidence for the role of newsprint media in encouraging males to make contact with helplines
}

This study explored the preliminary evidence for a relationship between constructive and affirming newsprint stories about depression or anxiety in males and use of helpline services by males. With the help of a Consumer Reference Group, we identified ten positive newsprint stories about males and depression or anxiety. We then obtained phone contact data from four national helplines in Australia: Lifeline, MensLine Australia, SANE Australia, and beyondblue. For each contact, we extracted the date, location and gender of the caller. Poisson regression analysis was used to determine the change in contact volume in the two weeks following each story, as compared to the two weeks prior to the story. Contact volume from males increased significantly in the two weeks after four of the ten stories, decreased after one story with no change after five of the stories. The stories that were associated with increased contacts were about men (including publicly revered role models) that male readers could identify with and tended to be stories of hope and recovery. The findings suggest newsprint media can positively influence male help-seeking and point to a need for articles to provide accurate representations of depression and anxiety, whilst maintaining an optimistic focus on recovery.

Key words: Men, males, depression, anxiety, media, newspapers, helpline, telephone, help-seeking 
The media is the public's primary source of information on mental illness (Anderson, 2003; Hannigan, 1999; Pirkis \& Francis, 2012) and plays an important role in shaping people's perceptions (Corrigan, Powell, \& Michaels, 2013; Wahl, 2004). The media can have a strong influence on people's behaviour in relation to mental illness and has the potential to promote help-seeking. The association between negative media reporting and behaviour has been clearly demonstrated in the established link between reporting of suicides and suicidal behaviour as well as research focusing on the stigma of mental illness and help seeking behaviour (Mojtabai, 2010; Pettigrew, Donovan, Pescud, Boldy \& Newton, 2010; Pirkis, Burgess, Francis, Blood \& Jolley, 2006). The association between positive media reporting of mental health and help seeking behaviour has received less research attention with current reviews suggesting a need to focus on how best to reach vulnerable populations to encourage help seeking whilst also aiming to further reduce stigma (Niederkrotenthaler, Reidenberg, Till, \& Gould 2014; Sisask \& Varnik, 2012; Stout, Villegas, \& Jennings, 2004).

\section{Social cognitive theory as an explanation for the influence of the media on attitudes and behaviour}

Social cognitive theory (Bandura, 1977, 2001) provides one explanation for the link between media representations of mental health and illness and help-seeking. This theory posits that self-efficacy is key for changing behaviours, including help-seeking, and that many of the expectations we hold about ourselves are derived from vicarious experience. The media presents us with an abundance of vicarious experiences every day, and a vast amount of information about human behavior and values is gained through the mass media (Bandura, 2001). Through these vicarious experiences, people 
persuade themselves that if others can change their behaviour, then so can they. The theory postulates that our self-efficacy increases the more we see others modelling successful behaviours, such that seeing others gain desired outcomes can function as a positive incentive for behaviour. Learning is further enhanced when others' thoughts regarding problem-solving can be observed. Role models can act not only to legitimise new practices, but also to advocate for new behaviours by directly encouraging others to adopt them.

A key element of social cognitive theory is that the observer identifies with the role model in some way, either holding them in high esteem or seeing them as being similar to themselves (Bandura, 2001). 'Everyday' people can act as models by providing examples of how positive results can be achieved by using similar conduct; this effect is enhanced by perceived similarity to the model (Bandura, 2001). Research on the reporting of suicide has also shown that a copycat effect is much more likely when the story is about a celebrity than when it is not (Bandura, 2001; Stack, 2000).

In relation to mental illness portrayed in the media, social cognitive theory would therefore predict that if people with mental health issues are presented with stories of others whom they see as similar to themselves or hold in high esteem successfully seeking help or recovering from mental illness, then they would learn from this; their self-efficacy would increase, and they would be more likely to similarly seek help for themselves and take other steps towards recovery.

\section{Australia's efforts in encouraging positive reporting of mental illness}

With the aim of encouraging responsible, accurate and sensitive representation of mental illness (and suicide) in the Australian mass media, the Hunter Institute of Mental Health has worked with the media via the Australian Government-funded Mindframe 
National Media Initiative. Mindframe has developed a resource for media professionals known as Reporting Suicide and Mental Illness (Health, 2014). The resource provides information about how to report mental illness in an accurate and balanced way.

There is evidence that the reporting of mental illness has improved in Australia since the release of Reporting Suicide and Mental Illness. The Media Monitoring Project explored the depiction of mental illness in Australian newspapers, television and radio over a 12-month period in 2000-2001(Francis et al., 2005; Pirkis et al., 2001), prior to the release of the Mindframe resource, and then again in 2006-2007(Pirkis et al., 2008). The project found improvements in the reporting of mental illness over this time on almost all indicators of quality including: more accurate headings, less stereotyping and more appropriate language.

\section{The potential for constructive and affirming media stories about mental illness to}

\section{have a positive influence on help-seeking}

Some work has been done exploring the impact of the media on people's thoughts and actions, but it has mostly focused on knowledge and attitudes. A recent review of studies found that mass media stigma reduction campaigns and documentary films can have positive effects on these (Corrigan,Powel \& Michaels, 2013). A recent laboratory based study suggested that exposure to films where a character successfully manages a mental health crisis may have beneficial effects for vulnerable individuals (Till, Strauss, Sonneck, \& Niederkrotenthaler, 2015). The self-efficacy and views of people with mental disorders in regard to their illness have been shown to have a clear association with public attitudes and behaviour, such that less stigmatising public attitudes are associated with lower rates of self-stigma (Evans-Lacko, Brohan, Mojtabai, $\&$ Thornicroft, 2012). There is scope for exploring this further, and considering 
whether media stories might also change behavior, and in particular encourage helpseeking. If this were so, it might provide opportunities for the media to improve awareness of mental health services, effectively creating an innovative pathway to care for individuals with mental health problems.

\section{Unique opportunities for the media to promote help-seeking in males}

The media's role in encouraging help-seeking behaviour may be particularly important for males with mental health problems. The 2007 National Survey of Mental Health and Wellbeing (NSMHWB) assessed lifetime and 12-month prevalence of mental disorders using a diagnostic screening tool (Kessler \& Ustun, 2004), and found that although males experienced lower rates of mental disorders in the past 12 months than females (18\% and 22\% respectively) (Australian Bureau of Statistics, 2007), they were significantly less likely to seek help (Andrews, Issakidis, \& Carter, 2001; Burgess et al., 2009). The NSMHWB found that although $41 \%$ of females with a mental disorder in the past 12 months had accessed help, only $28 \%$ of males had done so (Australian Bureau of Statistics, 2007). In addition to reduced help-seeking, males also often delay seeking help such that their symptoms are more severe when they start treatment as many males self-monitor and self-treat and hope that symptoms will disappear, before reluctantly seeking professional care (Oliffe \& Phillips, 2008).

Research suggests that males' decreased and delayed help-seeking is due to a number of interdependent factors. Males show a lower level of mental health literacy compared with females (Cotton, Wright, Harris, Jorm, \& Mcgorry, 2006; Swami, 2012) and experience higher levels of stigma (Wang, Fick, Adair, \& Lai, 2007; Wang \& Lai, 2008). It is perhaps not surprising then that research has also consistently demonstrated that males have more negative attitudes towards help-seeking for mental health 
problems (MacKenzie, Gekoski, \& Knox, 2006). In particular, traditional masculine behaviour and attitudes have been found to relate to reduced and delayed help-seeking for mental health problems (Boman \& Walker, 2010; Galdas, Cheater, \& Marshall, 2005; Kyung Nam et al., 2010; Levant, Wimer, Williams, Smalley, \& Noronha, 2009).

Males' reluctance to access health services in general has been cited as a key issue to be overcome in order to improve men's health (Galdas, Cheater, \& Marshall, 2005). Understanding and encouraging males' help-seeking behaviour in general is therefore an important focus for research and health policy.

\section{The current study}

This study sought to provide preliminary evidence regarding the potential for newsprint media to have an impact on men's help-seeking. This study used phone contacts with helplines as an indicator of help-seeking behaviour. Helplines in Australia receive an enormous number of phone contacts. For example, Lifeline 131114 receives around 1,800 phone contacts a day (Lifeline). There are many benefits to individuals accessing help from helplines: they are free or low cost, can be accessed immediately and at any time, and are anonymous and confidential and therefore can be felt to be less stigmatising than other forms of help. For these reasons, helplines may be an attractive first port of call for someone with a mental health issue. We know from Australian and international studies, however, that males are less likely to use helplines than females (Ingram et al., 2008; Ledek, Deane, Lambert, \& McKeehan, 2002; Watson, McDonald, \& Pearce, 2006).

The study explored whether there is a relationship between constructive and affirming (positive) newsprint stories about depression or anxiety in males and use of helpline services by males. Specifically, it sought to determine if positive stories in 
newsprint media about males with depression or anxiety are followed by an increase in phone contacts by males to helplines, and if so, what the features are of newsprint stories that might lead to such an increase.

Newsprint media was chosen for this study, rather than other media such as television, radio, or the various forms of online media. Newsprint media can be readily investigated through the use of online databases. Similar databases were not available in relation to other types of media (e.g. television and radio), and as such it was unfortunately beyond the scope of the study to investigate those media. However, a previous review has shown that newsprint media has a major influence on television news, and that there is also substantial overlap between stories in newspaper and stories in television, radio and online (McCombs \& Funk, 2011). Thus, it is likely that newsprint media stories provide a good representation of stories occurring in all media. Whilst newspaper readership is arguably falling, substantial numbers of people continue to access newspaper content via print, web or app. For instance, an estimated four million people accessed the main daily Sydney newspaper, 'The Sydney Morning Herald', in the year ending June 2016 (Roy Morgan Research, 2016). 


\section{Method}

\section{Consumer Reference Group}

A community based participatory research approach was used to guide the inclusion of a Consumer Reference Group in the study. Focus groups in community based participatory research are designed to 'ascertain perspectives, ideas, beliefs, opinions and attitudes on a preselected topic (Jackson et al., 2013, p115). They offer the potential to ground the findings in the lived experiences of members.

At the beginning of the study, a Consumer Reference Group was formed to provide input to the study design and to assist with the qualitative interpretation of the study findings. Our funder, beyondblue (an independent, not-for-profit organisation which works to increase awareness and understanding of anxiety and depression in Australia and to reduce the associated stigma) assisted us with recruiting this group. beyondblue sent an email to all members of blueVoices (its online community and reference group) on our behalf, inviting males with depression or anxiety to contact us by phone if they were interested in being part of the study's Consumer Reference Group. Eight males who self-identified as having depression or anxiety were recruited to form the group.

The Consumer Reference Group's first task was to assist us in selecting newsprint stories (described in more detail below). Specifically, the Consumer Reference Group provided input into the criteria for choosing these stories. The group met for 90 minutes on 13 August 2013 and took part in a semi-structured discussion that focused on the group's reflections on media stories that may have come to their attention as being likely to lead to help-seeking. They were also asked to consider two 
recent news print articles that we had already chosen, in relation to the features of the articles that might prompt men with depression or anxiety to seek help.

The Consumer Reference Group's second task, which occurred towards the end of the study, was to assist with the interpretation of the study's findings. A 90-minute meeting of the group was held on 21 January 2014. This meeting took the form of a semi-structured discussion within which the group members and the researchers collaborated on the qualitative analysis of the stories. Using a conventional content analysis method which allows for themes to flow from the data (Hsieh \& Shannon, 2005), the Consumer Reference Group was presented with each story and were asked to identify common themes that were associated with stories that were related to an increase in phone contacts to helplines, no change in phone contact, and a decrease in contacts. Themes were only recorded if a consensus among all the group members was reached.

\section{Newsprint stories}

The Consumer Reference Group indicated that stories that might promote help-seeking would be ones that removed the stigma around mental illness and demonstrated pathways to recovery. Specifically, they recommended that we should seek articles that: featured someone (a celebrity or other male role model) either disclosing their depression or anxiety or advocating on behalf of people with mental illness; included an accurate description of symptoms; provided information about pathways to help (e.g., described how the person in the story sought help, or mentioned sources of help); or featured an individual with whom males could identify. They also commented that the story need not always be about recovery or convey hopeful messages if the story provided thoughtful insight into a person's journey with depression or anxiety. 
The recommendations of the group aligned closely with the recommendations of the Mindframe resource, Reporting Suicide and Mental Illness (Health, 2011) (we used the 2011 version, however a newer version was published in 2014 (Health, 2014). This resource recommends that articles provide accurate information, encourage people to seek help, break down myths, allow people to tell their own story, and use appropriate language and avoid stereotypes. Drawing on the recommendations of the group and of the Mindframe resource Newsbank (a web based database of international newsprint media) was searched. The search was conducted using the term 'mental health' and restricted to Australian newsprint and was concentrated over a 13-month period: 1 July 2012 to 30 June 2013. Articles were selected if they were consistent with the majority of the group and Mindframe recommendations.

The researchers initially searched for stories independently and compiled a list. We then met to decide upon the final list of stories for analysis. The first shortlist comprised 14 stories. The list of stories was reduced to ten stories based upon consensus between the researchers regarding the degree to which each story was consistent with the established criteria. Four stories were discarded because they either did not focus on depression or anxiety, were less consistent with the criteria (compared to other stories), or were not thought to have a large enough audience to effect a change in contacts to helplines (for instance, stories that only comprised one small article).

In order to identify the individual articles that made up each of the ten stories, one of the researchers then conducted a further refined search, through Newsbank, of all newsprint articles featuring the words 'depression' or 'anxiety' that appeared in the media in the two weeks before and after the first article appeared in newsprint for each story.

Our refined search enabled us to ascertain the exact dates of the newsprint coverage of the story, what other coverage of depression and anxiety was occurring at the same time (which may have confounded our analyses) and whether there were other 
stories that might be more suitable for our analyses. A total of 13,324 newsprint articles featuring the words 'depression' or 'anxiety' were reviewed.

The search confirmed that the list of ten stories were suitable for inclusion in the study. For each story the following features were recorded: article title; date; the newspaper and location (state or territory) of the newspaper; a brief summary of the article; and whether helplines were mentioned in the article. The ten stories we selected occurred in the 13-month period July 2012-July 2013 and comprised 105 articles. Approximately $30 \%$ of these articles featured a helpline, which is an improvement in comparison to the $17.7 \%$ of suicide related media coverage that featured a helpline in a 2006/07 study of Australian media (Pirkis, et al., 2009).

\section{Helpline phone contact data}

Data on phone contacts to helplines were obtained from four Australian helplines:

Lifeline, MensLine Australia, SANE Australia, and beyondblue. Each of these organisations operates a national helpline, and although they differ slightly in their target group, they each provide telephone information, advice and referral.

All of the helplines provided us with raw data in Excel spreadsheets that related to phone contacts with their service. We sought five years of data in order that any annual fluctuations in contact volume could be identified. Four of the helplines provided data for the five-year period 1 September 2008 to 31 August 2013. One of the helplines provided data from 1 September 2009 to 31 August 2013. Data were collated across the helplines.

The method of data collection varied somewhat between the helplines but there were some commonalities. For each of the helplines, the telephone or online system automatically populated a central database with some information about when the 
contact occurred and how long it lasted. Data on the caller's characteristics and the nature of the contact were entered into the database by telephone staff (paid and volunteer). The specific data collected varied between the helplines, with the number of variables and the quality of data generally increasing over the five years. One of the helplines received substantially more phone contacts than the other three.

\section{Data management and analysis}

We extracted the date, gender and location (state or territory) of each phone contact. Simple frequencies and negative binomial regression analyses were used to determine seasonal variation in phone volume. To ascertain change in volume of phone contacts a series of variables were created which identified the before and after date range for each media story (based on the date that the first article for each story appeared). The time frame of two weeks was used (i.e., a fortnight before and after each story started), as previous research indicates that this may be the time within which the media can directly impact on behaviour. Research on the relationship between media reporting of suicide and actual suicide suggested that the impact of media stories peak within the first three days and then drops off by about two weeks (Pirkis, Burgess, Francis, Blood, $\&$ Jolley, 2006). We were able to further improve on the quality of the data by excluding phone contacts that were less than 60 seconds long (which were likely not to be meaningful phone contacts with the service, such as hang ups, hoax phone contacts etc.). Poisson regression analysis was used to determine the change in phone contact volume following each story for male and female callers in separate analyses. Nine of the stories were national, and for these stories national data were analysed. One of the stories occurred in only one state of Australia (New South Wales), so only phone 
contact data identified as originating from this state were analysed for this story. Data analysis was performed using Stata version 12 and SPSS version 21. 


\section{Results}

\section{Description of media stories}

The ten stories included two regarding the Olympic swimmer Ian Thorpe, one about a retired Army Major (John Cantwell), two regarding two other Olympic athletes (Edward Fernon and Matthew Mitcham), one about a football player (Harry O’Brien), two on mental health campaigns run by beyondblue (Get to Know Anxiety, Man Therapy), one about a journalist (David Smiedt), and one about a female DJ (Ruby Rose). Most of the stories featured individuals disclosing their experience with depression or anxiety. It is worth noting that although the two Ian Thorpe stories were related to significant events that occurred, a television interview and a book release, the newsprint coverage of these stories predated both events. For instance, the newsprint articles related to the television interview started on July 82012 , but the interview itself did not occur until July 15 . The newsprint articles related to the book release began on October 13 2012, but the book was not published until Nov 1 2012. However, the newsprint coverage related the campaigns began at the same time as the campaigns. The features of these stories, in terms of the date the story began, the number of articles and whether helplines were mentioned, are described in Table 1.

[Table 1 about here]

Changes in numbers of phone contacts with helplines by males following selected newsprint stories

Table 2 presents the results of the Poisson regression analysis undertaken to determine whether the newsprint stories were followed by an increase in phone contacts by males 
to the helplines. Note that the date that the first article related to the story appeared in newsprint is taken as the start date for the story. There were significant changes in male phone contact volume after four of the stories. Phone contact volume increased after the following stories: beyondblue's Get to Know Anxiety campaign (by about 50 more phone contacts per day), the reporting of Ian Thorpe's television interview (by 35 contacts per day), Ian Thorpe's book release (29 contacts per day) and beyondblue's Man Therapy campaign (26 contacts per day).

There were no significant differences in the volume of phone contacts in the two weeks following the stories of Edward Fernon, Matthew Mitcham, Harry O'Brien, Ruby Rose and David Smiedt. The phone contact volume significantly decreased (by about 55 phone contacts per day) in the two weeks after the Major John Cantwell story.

[Table 2 about here]

An analysis of contacts made by females was undertaken to determine whether the changes noted in contacts by males were specific to males or general to all contacts. Table 3 presents female helpline activity in the two weeks before and after each media story in terms of the total number of phone contacts in the time period, the incidence ratio along with the confidence interval, and associated $\mathrm{p}$ value. As with the males, there was an increase in helpline phone contacts in the two weeks following the reporting of Ian Thorpe's television interview and book release (72 and 29 contacts per day), and the beyondblue Man Therapy (29 contacts), and a decrease following the John Cantwell story (72 contacts). By contrast, however, the volume of female phone contacts also significantly increased in the two weeks following the stories about Matthew Mitcham (41 contacts) and Ruby Rose (36 contacts), and there was no change in female phone contacts after the beyondblue Get to Know Anxiety campaign. 
The results therefore suggest that the response of males to the articles was somewhat different to that of females. Qualitative analysis of the articles was therefore limited to the impact of the articles on males.

[Table 3 about here]

\section{Typical patterns of phone contacts with helplines}

We also considered whether our results could be attributed to seasonal variations in call volumes. Figure 1 shows the number of phone contacts received by the four helplines, by month, from 1 September 2008 to 31 August 2013. Over this time there were $2,862,069$ phone contacts to the helplines. Of these, $31 \%$ were made by males and $46 \%$ were made by females (gender was unknown in $22 \%$ of calls). Some minor patterns in contact volume were noted. The volume appeared to increase towards the end of the year in October, November and December, then decrease in January, and plateau in the first half of the year. As our primary analysis focused on a two weeks period either side of each story we were reasonably confident that the analysis would not be dominated by any major seasonal variations. We examined these variations further in a series of binomial regression analyses. As shown in Tables 4-6 the increases in call volumes after a newsprint story did not appear to be reflective of an ongoing seasonal increase in calls.

That is, we did not find a consistent increase in calls when we consider the same fortnight periods in previous years, regardless of whether we analysed calls overall or by gender.

[Figure 1 about here]

[Tables $4,5 \& 6$ about here] 


\section{Possible explanations for increases in phone contacts with helplines by males after specific newsprint stories}

With the aid of the Consumer Reference Group, we identified characteristics of the stories that may have influenced whether the story was associated with an increase, decrease or no change in phone contacts to helplines by males. A qualitative analysis of the stories was undertaken with the group. They were asked to identify recurring themes in the content of the stories that resulted in increased phone contact, no change in phone contact, and decreased phone contact. Only themes that were generated from a consensus of all members are presented.

\section{Increased phone contact}

The two Ian Thorpe stories were quite similar in that they both discussed Ian Thorpe's depression, in the context of a television appearance and the other in the context of a book release. The Consumer Reference Group commented that these stories might be influential for two main reasons. Firstly, the group suggested that Ian Thorpe was a role model for males; he was someone looked up to and identified with as being similar to them having watched his career for many years. Secondly, they noted that his story was one of hope and recovery as many articles detailed overcoming mental health concerns and, as such, was quite inspirational.

The Consumer Reference Group were not surprised that the stories about the two beyondblue campaigns, Get to Know Anxiety and Man Therapy, were associated with increased phone contacts to helplines since encouraging help-seeking was an explicit aim of both campaigns. The group felt that males with depression or anxiety 
would easily identify with the characters (e.g., Dr Brian Ironwood or anxiety personified by actor Ben Mendelsohn) and celebrities (e.g., actor Garry McDonald) and that the campaigns were successful in addressing the stigma associated with mental illness and promoting help-seeking. The group also noted that the campaign coverage was from a trusted source (a well-known 'brand') and widespread, appearing not only in newspapers but also in advertising in public spaces.

Overall, the Consumer Reference Group commented that the most important factors in the stories that were associated with increases in phone contacts were that males could identify with the protagonists and that they were stories of hope and recovery from trusted sources.

\section{No change in phone contact}

Consistent with their previous suggestions, the Consumer Reference Group suggested that the reason the five stories were not associated with any increases in male phone contacts to helplines was because males might not relate to the people featured in the stories, and therefore they would be unlikely to influence them to seek help. The Consumer Reference Group spent some time discussing the Harry O'Brien story. This story received extensive newsprint coverage, and helplines were sometimes mentioned; however no increase in phone contacts was noted. The group suggested that although the story had the potential to provide a means for men to relate to O'Brien's experience of depression, and some of the earlier articles described the support received by O'Brien from his football club, the media unfortunately reported the story poorly. O'Brien's erratic behaviour was the focus of many of the articles. They also noted that the Edward Fernon, Ruby Rose and Harry O’Brien stories did not focus on recovery. 


\section{Decreased phone contact}

The Consumer Reference Group suggested that whilst the John Cantwell story may have contributed to stigma reduction by identifying a well-known respected man's journey through depression, the story was otherwise quite negative and did not focus on the hopeful aspects of Cantwell's journey.

\section{Discussion}

This study sought to establish the preliminary evidence regarding the relationship between constructive and affirming (positive) newsprint stories about depression or anxiety in males and males' help-seeking behaviour as indicated by their use of helpline services.

Of the ten stories analysed, four were associated with an increase in the number of phone contacts made to helplines by males in the two weeks following the story. Five stories resulted in no change in phone contacts to helplines, and one story resulted in decreased phone contacts.

The four stories that were associated with an increase in phone contacts to helplines by males were differentiated from the other stories by being stories about hope and recovery that featured males who were either revered or could be easily identified with.

The findings are consistent with social cognitive theory, which postulates that role modelling of successful behaviours by people who are held in high esteem or identified with will lead to behaviour change in those observing them. In this instance, as males see Ian Thorpe, Garry McDonald and the fictional Dr Ironwood model and advocate for recovery and help-seeking, their self-efficacy and incentive to change may increase, leading to their own help-seeking. Conversely, stories that were not hopeful or 
that featured people with whom males could not identify were not associated with a positive change in phone contacts to helplines.

Although the analysis is not described in this paper, consideration was given to patterns of phone contacts between the individual helplines. There were some similarities. Most of the helplines trended towards similar increases in call volumes after the key stories. This finding suggests that media stories may have the potential to increase help-seeking in general, not just to a featured help source. This observation is further supported by the finding that two of the stories that resulted in an increase in phone contacts to helplines did not mention helplines at all. It may be that the helplines have a significant profile in Australia with good awareness by the public, such that they are readily seen as a support for those with mental health concerns. Alternatively, it could be that these media stories increase help-seeking to many sources of support. It would be interesting to know whether there were commensurate increases in males' seeking help from other sources such as GPs, psychologists, and community-based mental health services.

There were some commonalities between males' patterns of calls to helplines following the stories and those of females. The largest increase in phone contacts was seen for both males and females following the reporting of Ian Thorpe's television interview, which could suggest that females may have also been able to identify with Ian Thorpe's story of recovery. Both males and females also contacted the helplines in increased numbers after the Ian Thorpe book release and the Man Therapy campaign stories. However, there were also some gender differences in calling patterns after the stories. For instance, there was no increase in females' contacts with helplines following the Get to Know Anxiety campaign, perhaps because this was strongly focussed on males in its early days. By contrast, we found an increase in numbers of callers in the period following the only story in our corpus about a woman: Ruby Rose. Also, when the percent increase in phone contacts was considered, rather than the absolute number 
of contacts, more males than females appeared to react by seek helping after the stories about Ian Thorpe's book release (5.5\% increase for males vs. 3.6\% for females) and the Man Therapy campaign (3.9\% for males vs. 3.3\% for females). These findings suggest that males reacted to the stories somewhat differently from females.

\section{Limitations}

Our results suggest an association between certain newsprint stories and phone contacts to helplines by males, but we are not able to definitively know if this association is causal. For instance, we are not able to know if those calling the helplines viewed the newsprint stories; neither do we know what else may have been occurring that may have prompted them to make contact. It is worth noting that although the two Ian Thorpe stories were related to significant events that occurred in other mediums that could have also impacted on calls to helplines, a television interview and a book release, the newsprint coverage of these stories, and the corresponding increase in contacts to helplines, predated both events. For instance, the newsprint articles related to the television interview started on July 8 2012, but the interview itself did not occur until July 15. The newsprint articles related to the book release began on October 132012 , but the book was not published until November 12012 . However, the newsprint coverage related the campaigns began at the same time as the campaigns. It is therefore possible that other campaign activity impacted on helpline calls.

The study was also limited by its focus on newsprint articles only. The study did not explore other media such as television, radio and social media or online versions of the newsprint articles. Thus, it was not possible to gauge the true scope of the stories. However, it is likely that the size and reach of the newspaper story was reflective of its size and reach in other media. 


\section{Further Research}

Further research efforts are needed to improve our understanding of how we can facilitate and improve men's help seeking. The findings of this study suggest that the media can be harnessed to this end. However, we need to know more about men's interaction with the media. A larger scale study that includes other forms of media and searches exhaustively for all relevant stories occurring over a given period, could help us to understand more about the specific features of stories that result in increased helpseeking by males. Furthermore, it may help us to consider some of the unique features of online media such as how far (in space and time) people search for online media and how they view online interactions with the news pieces (e.g., read comments and opinions) (Sisask \& Varnik, 2012). Such research could also include other avenues of help, such as the web-based 'chat' and online forum services now provided by many helplines. The findings of such research could assist the media to present news stories in ways that are most likely to positively impact on men's help seeking. This could even be used strategically at times of particular need, for instance following events that can negatively impact on men's mental health such as social crises or traumatic events.

\section{Conclusions}

The findings of this pilot study provide suggestive evidence that newsprint media can have a positive impact on the help-seeking behaviour of males. The findings point to the need for articles to provide accurate representations of depression and anxiety, whilst 
maintaining an optimistic focus on recovery. The use of role models may be particularly useful in promoting help-seeking. 


\section{References}

Anderson, M., (2003).'One flew over the psychiatric unit': mental illness and the media. Journal of Psychiatric and Mental Health Nursing, 10, 297-306.

Andrews, G., Issakidis, C. \& Carter, G. (2001). Shortfall in mental health service utilisation. British Journal of Psychiatry, 179, 417-425.

Australian Bureau of Statistics, (2007), National survey of mental health and wellbeing: summary of results.4326.0: Canberra.

Bandura, A., (1977). Self-efficacy: Toward a unifying theory of behavioral change. Psychological Review, 84(2), 191-215.

Bandura, A., (2001). Social cognitive theory of mass communication. Medipsychology, 3, 265-299.

Boman, E.K.O., \& Walker, G.A. (2010). Predictors of men's health care utilization. Psychology of Men \& Masculinity, 11(2), 113-122.

Burgess, P., Pirkis, J., Slade, T., Johnston, A., Meadows, G., Gunn, J(2009). Service use for mental health problems: findings from the 2007 National Survery of Mental Health and Wellbeing. Australian and New Zealand Journal of Psychiatry, 43, 615-623.

Corrigan, P.W., Powell, K.J., \& Michaels, P.J., (2013). The effects of news stories on the stigma of mental illness. The Journal of Nervous and Mental Disease, 201(3), 179-182.

Cotton, S.M., Wright, A., Harris, M.G., Jorm, A.F., \& McGorry, P.D. (2006). Influence of gender on mental health literacy in young Australians. Australian and New Zealand Journal of Psychiatry, 40, 790-796.

Evans-Lacko, S., Brohan, E., Mojtabai, R., \& Thornicroft, G., (2012). Association between public views of mental illness and self-stigma among individuals with 
mental illness in 14 European countries. Psychological Medicine. 42(8), 17411752.

Francis, C., et al., (2005). Portrayal of depression and other mental illness in Australian nonfiction media. Journal of Community Psychology, 2005. 33(3), 238-297.

Galdas, P.M., Cheater, F., \& Marshall, P. (2005). Men and health help-seeking behaviour: literature review. Journal of Advanced Nursing, 49(6), 616-622.

Hang, H. \& Shannon, S. (2005). Three approaches to qualitative content analysis. Qualitative Health Research, 15(9), 1277-1288.

Hannigan, B., (1999). Mental health care in the community: An analysis of contemporary public attitudes towards, and public representations of, mental illness. Journal of Mental Health, 8(5), 431-440.

Health, H.I.o.M., (2011). Reporting Suicide and Mental Illness: a Mindframe resource for media professionals, Australian Government Department of Health, Editor: Newcastle.

Health, H.I.o.M., (2014). Reporting suicide and mental illness: A Mindframe resource for media professionals, Australian Government Department of Health, Editor: Newcastle.

Ingram, S., et al., (2008). Coping with crisis across the lifespan: the role of a telephone hotline. Journal of Child and Family Studies, 17, 663-674.

Jackson, F.M., Saran, A., Graham Johnson, P. \& Morris, S.J. (2013). Qualitative research in CBPR. In Braithwaite, R.L. (Ed). Community-Based Participatory Health Research, Second Edition. Springer Publishing Company.

Kessler, R.C., \& Ustun, T.B. (2004). The World Mental Health (WMH) survey initiative version of the World Health Organization (WHO) Composite International Diagnostic Interview (CIDI). International Journal of Methods in Psychiatric Research, 13(2), 93-121. 
Kyung Nam, S., et al., (2010). A meta-analysis of gender differences in attitudes toward seeking professional psychological help. Journal of American College Health, 59(2), 110-116.

Ledek, V., Deane, F., Lambert., G., \& McKeehan, C. (2002). Description of a rural Australian free call telephone mental health information and support service. Australasian Psychiatry, 10(4), 365-370.

Levant, R.F., Wimer, D.J., Williams, C.M., Smalley, K.B. \& Noronha, D. (2009). The relationships between masculinity variables, health risk behaviors and attitudes toward seeking psychological help. International Journal of Men's Health, 8(1), $3-21$.

Lifeline. About Lifeline. (14 March 2014); Available from: http://www.lifeline.org.au/About-Lifeline.

McCombs, M., \& Funk, M. (2011). Shaping the agenda of local daily newspapers: A methodology merging the agenda setting and community structure perspectives. Mass Communication and Society, 14, 905-919.

MacKenzie, C., Gekoski, W., \& Knox, V. (2006). Age, gender, and the underutilization of mental health services: The influence of help-seeking attitudes. Aging and Mental Health, 10(6), 574-582.

Mojtabai, R. (2010).Mental illness stigma in and willingness to seek mental health care in the European Union. Social Psychiatry and Psychiatric Epidemiology, 45, 705-12.

Niederkrotenthaler, T., Reidenber, D.J., Till, B., Gould, M.S. (2014). Increasing helpseeking and referrals for individuals at risk for suicide by decreasing stigma: The role of the mass media. American Journal of Preventive Medicine, 47 (3S2), S235-S243.

Oliffe, J.L. \& Phillips, M.J. (2008). Men, depression and masculinities: A review and recommendations. Journal of Men's Health, 5(3), 194-202. 
Pettigrew, S., Donovan, R., Pescud, M., Boldy, D., \& Newton, R. (2010). Mature adults' attitudes to mental health utilisation. Australian Psychologist, 45, 14150.

Pirkis, J., Blood, R.W., Dare, A., \& Holland K. (2008). The Media Monitoring Project: Changes in media reporting of suicide and mental health and illness in Australia: 2000/01-2006/07. Department of Health and Ageing: Canberrra.

Pirkis, J., Burgess, P., Francis, C., Blood, R., \& Jolley D. (2006). The relationship between the media reporting of suicide and actual suicide in Australia. Social Science and Medicine, 62, 2874-2886.

Pirkis, J., Dare, A., Blood, R., Rankin, B., Williamson, M., Burgess, P., et al. (2009). Changes in media reporting of suicide in Australia between 2000/01 and 2006/07. Crisis, 30(1), 25-33.

Pirkis, J. \& Francis, C., (2012) Mental illness in the news and the information media: a critical review, in Mindframe National Media Initiaitve, Mindframe.

Pirkis, J., Blood, R.W., Francis, C., Putnis, P., Burgess, P., Morley, B., ... Payne, T. (2001). The Media Monitoring Project: A baseline description of how the Australian media report and portray suicide and mental illness. Department of Health and Aged Care: Canberra.

Roy Morgan Research (2016) Newspaper cross-platform audience, 12 months to June 2016. Retrieved from http://www.roymorgan.com/industries/media/readership/cross-platformaudiences-newspapers. Sept 8, 2016.

Sisask, M., \& Varnik, A. (2012). Media roles in suicide prevention: A systematic review. International Journal of Environmental Research and Public Health, 9, 123-138.

Stack, S., (2000). Media impacts on suicide: A quantitative review of 293 findings. Social Science Quarterly, 81(4), 957-971. 
Stout, P.A., Villegas, J., \& Jennings, N.A. (2004). Images of mental illness in the media: Identifying gaps in the research. Schizophrenia Bulletin, 30, 543-561.

Swami, V., (2012). Mental health literacy of depression: gender differences and attitudinal antecedents in a representative British sample. PLoSONE, 7(11), e49779. doi:10.1371/journal.pone.0049779.

Till, B., Strauss, M., Sonneck, G., \& Niederkrotenthaler, T. (2015). Determining the effects of films with suicidal content: A laboratory experiment. The British Journal of Psychiatry, 207, 72-78.

Wahl, O.F., (2004). Stop the presses. Journalistic treatment of mental illness, in Cultural sutures. Medicine and media, L.D. Friedman, Editor, Duke University Press: Durkheim, NC. p. 55-69.

Wang, J. \& Lai, D. (2008). The relationship between mental health literacy, personal contacts and personal stigma against depression. Journal of Affective Disorders, 110, 191-196.

Wang, J., Fick, G., Adair, C., \& Lai, D. (2007). Gender specific correlates of stigma toward depression in a Canadian general population sample. Journal of Affective Disorders, 103, 91-97.

Watson, R., McDonald, J., \& Pearce, D., (2006). An exploration of national calls to Lifeline Australia: social support or urgent suicide intervention? British Journal of Guidance and Counselling, 34, 471-482. 


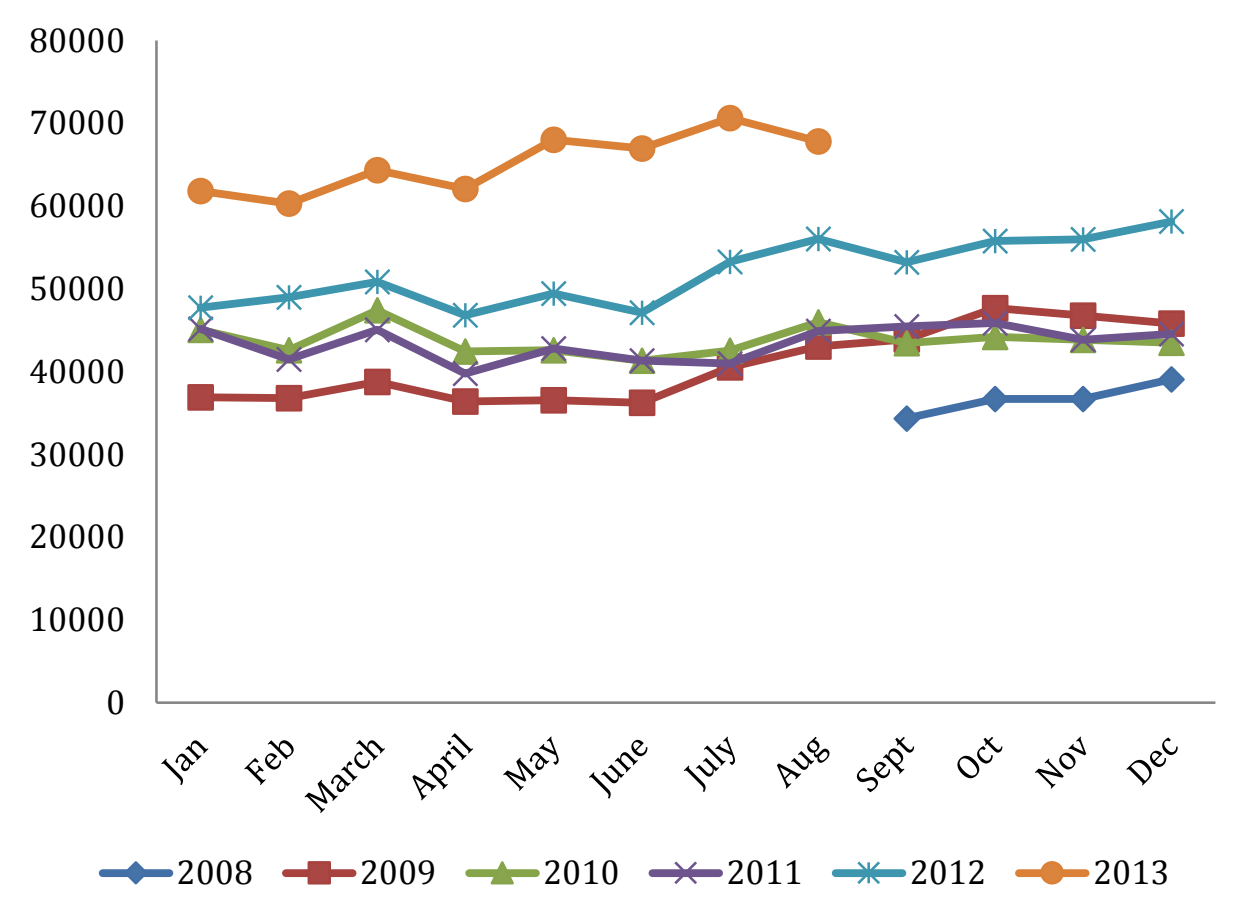

Figure 1: Contacts to helplines by year and month 
Table 1. Summary of newsprint stories selected for analysis.

\begin{tabular}{|c|c|c|c|c|c|}
\hline Story & $\begin{array}{l}\text { First } \\
\text { article }\end{array}$ & $\begin{array}{l}\text { No. } \\
\text { articles }\end{array}$ & Summary of story & $\begin{array}{l}\text { No. } \\
\text { Helplines }\end{array}$ & Helplines or websites mentioned \\
\hline $\begin{array}{l}\text { Ian Thorpe } \\
\text { television interview }\end{array}$ & $\begin{array}{l}8 \text { July } \\
2012\end{array}$ & 8 & $\begin{array}{l}\text { Ian Thorpe's (Olympic swimmer) TV appearance in which he discusses } \\
\text { his depression. }\end{array}$ & 0 & None \\
\hline David Smiedt & $\begin{array}{l}9 \text { Sept } \\
2012\end{array}$ & 1 & $\begin{array}{l}\text { Smiedt (comedian, blogger, newspaper contributor describes his } \\
\text { experience with depression (New South Wales only). }\end{array}$ & 1 & R U OK day website \\
\hline John Cantwell & $\begin{array}{l}22 \text { Sept } \\
2012\end{array}$ & 6 & $\begin{array}{l}\text { Cantwell's (retired army Major) experience with PTSD and depression } \\
\text { is described in the context of his book release. }\end{array}$ & 0 & None \\
\hline Edward Fernon & $\begin{array}{l}1 \text { Oct } \\
2012\end{array}$ & 5 & $\begin{array}{l}\text { Fernon's (Olympic pentathelete) horse ride that retraced the steps of a } \\
\text { historically significant horse to raise awareness of depression. }\end{array}$ & 0 & None \\
\hline $\begin{array}{l}\text { Ian Thorpe book } \\
\text { release }\end{array}$ & $\begin{array}{l}13 \text { Oct } \\
2012\end{array}$ & 3 & $\begin{array}{l}\text { Thorpe's book release with a focus on his 'inner demons' of depression } \\
\text { and alcohol use. }\end{array}$ & 2 & $\begin{array}{l}\text { Suicide helpline, Lifeline, MensLine Australia, } \\
\text { beyondblue helpline. }\end{array}$ \\
\hline Matthew Mitcham & $\begin{array}{l}17 \text { Nov } \\
2012\end{array}$ & 10 & $\begin{array}{l}\text { Mitcham's (Olympic diver) drug use and depression. The story } \\
\text { coincides with 'Movember' (male mental health campaign). }\end{array}$ & 0 & None \\
\hline Ruby Rose & $\begin{array}{l}1 \text { April } \\
2013\end{array}$ & 16 & Rose's (female DJ) cancellation of her DJ tour due to her depression. & 3 & Lifeline \\
\hline $\begin{array}{l}\text { Get to Know } \\
\text { Anxiety Campaign }\end{array}$ & $\begin{array}{l}6 \text { May } \\
2013\end{array}$ & 13 & $\begin{array}{l}\text { beyondblue's Anxiety campaign. Garry McDonald (actor) discusses his } \\
\text { anxiety and Ben Mendelsohn (actor) features in campaign material. }\end{array}$ & 5 & beyondblue helpline and website \\
\hline $\begin{array}{l}\text { Man Therapy } \\
\text { Campaign }\end{array}$ & $\begin{array}{l}5 \text { June } \\
2013\end{array}$ & 15 & $\begin{array}{l}\text { beyondblue's Man Therapy campaign, which targeted males and } \\
\text { featured the comical fictional character Dr Ironwood. }\end{array}$ & 13 & $\begin{array}{l}\text { Man Therapy website, beyondblue helpline, Lifeline, } \\
\text { headspace, kids helpline, suicide call back line }\end{array}$ \\
\hline Harry O'Brien & $\begin{array}{l}9 \text { July } \\
2013\end{array}$ & 28 & $\begin{array}{l}\text { Harry O'Brien's (well-known footballer) personal troubles including } \\
\text { depression. }\end{array}$ & 8 & Lifeline, MensLine Australia, beyondblue helpline \\
\hline
\end{tabular}


Table 2. Male helpline phone contacts in the two weeks before and after each media event: Total number and rate ratio

\begin{tabular}{lllll}
\hline Media Story & $\begin{array}{l}\text { Total } \\
\text { contacts } \\
\text { before }\end{array}$ & $\begin{array}{l}\text { Total } \\
\text { contacts } \\
\text { after }\end{array}$ & $\begin{array}{l}\text { Rate Ratio } \\
(95 \% \mathrm{CI})\end{array}$ & p value \\
\hline Ian Thorpe television interview & 7,124 & 7,618 & $1.07(1.03-1.10)$ & $<0.001$ \\
David Smiedt & 2,094 & 2,171 & $1.04(0.98-1.10)$ & 0.238 \\
John Cantwell & 8,051 & 7,281 & $0.90(0.88-0.93)$ & $<0.001$ \\
Edward Fernon & 7,651 & 7,555 & $0.99(0.96-1.02)$ & 0.436 \\
Ian Thorpe book release & 7,458 & 7,870 & $1.06(1.02-1.09)$ & $<0.001$ \\
Matthew Mitcham & 8,130 & 8,294 & $1.02(0.99-1.05)$ & 0.201 \\
Ruby Rose & 8,757 & 8,656 & $0.99(0.96-1.02)$ & 0.444 \\
beyondblue Get to Know Anxiety & 8,474 & 9,173 & $1.08(1.05-1.11)$ & $<0.001$ \\
campaign & 9,270 & 9,632 & $1.04(1.01-1.07)$ & 0.001 \\
beyondblue Man Therapy campaign & 9,773 & 10,034 & $1.03(1.00-1.06)$ & 0.064 \\
Harry O'Brien & & & & \\
\hline
\end{tabular}


Table 3. Female helpline phone contacts in the two weeks before and after each media event: Total number and rate ratio

\begin{tabular}{|c|c|c|c|c|}
\hline Media Story & $\begin{array}{l}\text { Total } \\
\text { contacts } \\
\text { before }\end{array}$ & $\begin{array}{l}\text { Total } \\
\text { contacts } \\
\text { after }\end{array}$ & $\begin{array}{l}\text { Rate Ratio } \\
(95 \% \mathrm{CI})\end{array}$ & $\mathrm{p}$ value \\
\hline $\begin{array}{l}\text { Ian Thorpe television } \\
\text { interview }\end{array}$ & 10,378 & 11,383 & $1.09(1.07-1.12)$ & $<0.001$ \\
\hline David Smiedt & 3,732 & 3,762 & $1.01(0.97-1.06)$ & 0.653 \\
\hline John Cantwell & 12,035 & 11,036 & $0.92(0.89-0.94)$ & $<0.001$ \\
\hline Edward Fernon & 11,391 & 11,232 & $0.99(0.96-1.01)$ & 0.285 \\
\hline Ian Thorpe book release & 11,121 & 11,526 & $1.04(1.01-1.06)$ & 0.007 \\
\hline Matthew Mitcham & 11,754 & 12,331 & $1.05(1.02-1.08)$ & $<0.001$ \\
\hline Ruby Rose & 12,065 & 12,571 & $1.06(1.04-1.09)$ & $<0.001$ \\
\hline $\begin{array}{l}\text { beyondblue Get to Know } \\
\text { Anxiety campaign }\end{array}$ & 12,054 & 11,991 & $1.01(0.98-1.03)$ & 0.486 \\
\hline $\begin{array}{l}\text { beyondblue Man Therapy } \\
\text { campaign }\end{array}$ & 12,396 & 12,799 & $1.03(1.00-1.05)$ & 0.037 \\
\hline Harry O'Brien & 12,492 & 12,750 & $1.02(1.00-1.05)$ & 0.055 \\
\hline
\end{tabular}


Table 4. Male helpline contacts in the two weeks before and after each media event, comparison to previous years:

Total number and rate ratio

\begin{tabular}{lclll}
\hline Media story & & & & \\
& Total contacts before & Total contacts after & Rate Ratio $(95 \%$ CI $)$ & p value \\
\hline Ian Thorpe television interview & & & 0.0001 \\
Year 4 & 3431 & 3451 & $0.58(-4.06-5.4)$ & \\
Year 3 & 5124 & 5170 & $0.90(-2.93-4.87)$ & \\
Year 2 & 5516 & 5559 & $0.78(-2.93-4.87)$ & \\
Year 1 & 5391 & 5529 & $2.56(-1.22-6.48)$ & \\
Year of Media Story & 7830 & 8670 & $10.73(7.40-14.16)$ & \\
\hline David Smiedt & & & & \\
Year 4 & 1336 & 1247 & $-6.70(-13.59-0.83)$ & \\
Year 3 & 1657 & 1480 & $-10.68(-16.73--4.20)$ & \\
Year 2 & 1665 & 1712 & $2.80(-3.89-10)$ & \\
Year 1 & 1420 & 1468 & $3.38(-3.89-11.2)$ & \\
Year of Media Story & 2239 & 2334 & $4.24(-1.63-10.47)$ & \\
\hline John Cantwell & & & $-3.90(-7.76-0.12)$ & \\
Year 4 & 4668 & 4486 & $2.46(-1.2-6.25)$ & \\
Year 3 & 5738 & 5879 & $-4.78(-8.2--1.3)$ & \\
Year 2 & 6019 & 5731 & & \\
\hline
\end{tabular}




\begin{tabular}{|c|c|c|c|c|}
\hline Year 1 & 6169 & 5935 & $-3.79(-7.16--0.3)$ & \\
\hline Year of Media Story & 8696 & 7900 & $-9.20(-11.88--6.44)$ & \\
\hline Edward Fernon & & & & 0.7309 \\
\hline Year 4 & 4517 & 4561 & $0.97(-3.1-5.21)$ & \\
\hline Year 3 & 6032 & 5948 & $-1.39(-4.86-2.2)$ & \\
\hline Year 2 & 5748 & 5810 & $1.10(-2.54-4.8)$ & \\
\hline Year 1 & 5951 & 6038 & $1.00(-2.11-5.16)$ & \\
\hline Year of Media Story & 8349 & 8280 & $-0.83(-3.8-2.2)$ & \\
\hline Ian Thorpe book release & & & & 0.2109 \\
\hline Year 4 & 4529 & 4660 & $2.89(-1.23-7.19)$ & \\
\hline Year 3 & 5926 & 6086 & $2.70(-0.91-6.44)$ & \\
\hline Year 2 & 5789 & 6050 & $4.51(0.81-8.34)$ & \\
\hline Year 1 & 5951 & 6059 & $1.81(-1.76-5.52)$ & \\
\hline Year of Media Story & 8137 & 8717 & $7.13(3.94-10.4)$ & \\
\hline Matthew Mitcham & & & & $<0.0001$ \\
\hline Year 4 & 4908 & 5111 & $4.00(0.1-8.3)$ & \\
\hline Year 3 & 6330 & 6449 & $1.88(-1.9-5.51)$ & \\
\hline Year 2 & 5758 & 5858 & $1.70(-1.9-5.5)$ & \\
\hline Year 1 & 6300 & 5604 & $-11.10(-14.2--7.8)$ & \\
\hline Year of Media Story & 8775 & 8981 & $2.00(-0.62-5.4)$ & \\
\hline
\end{tabular}




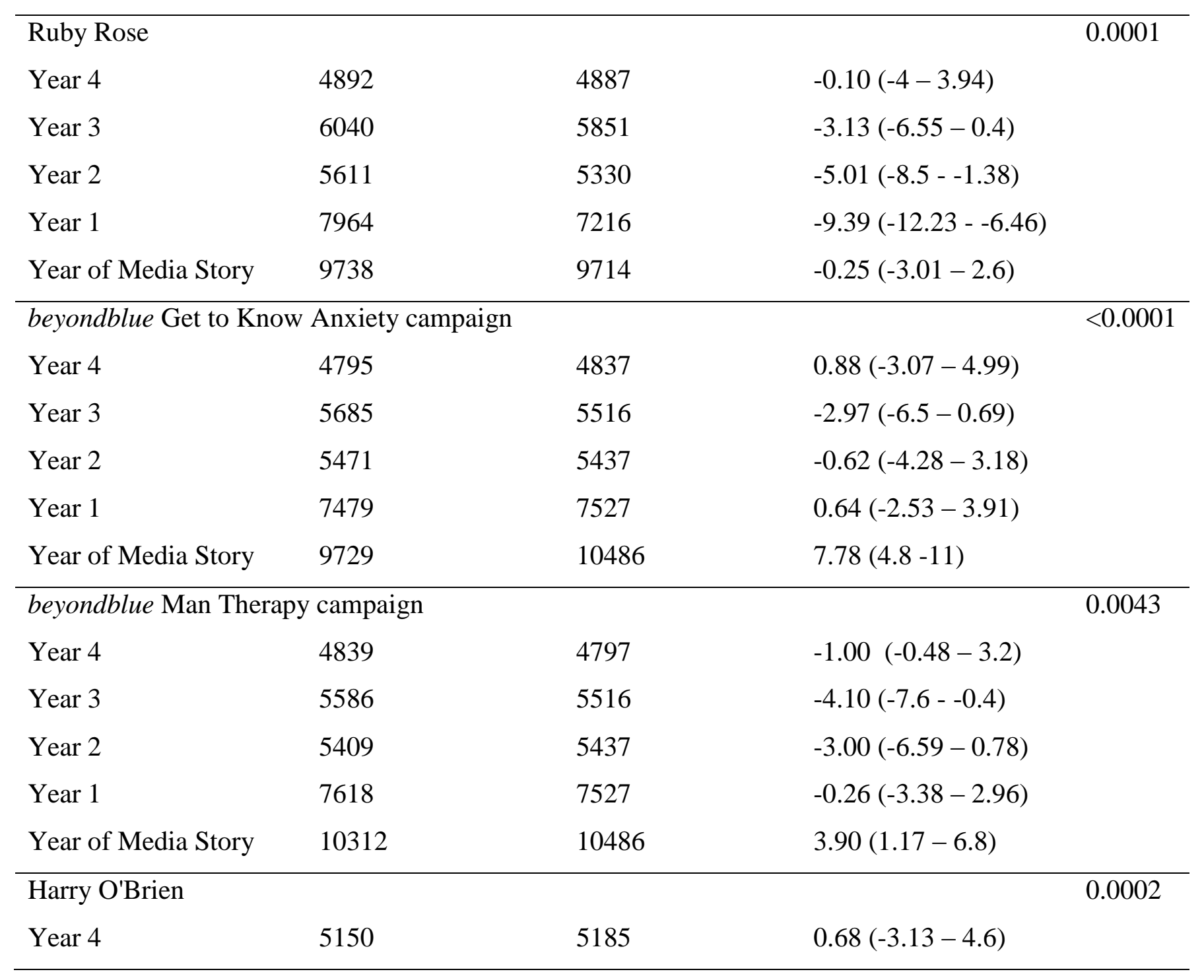




\begin{tabular}{llll}
\hline Year 3 & 5505 & 5624 & $2.16(-2-6)$ \\
Year 2 & 5400 & 5523 & $2.28(-1.49-6)$ \\
Year 1 & 7821 & 8670 & $10.86(7.5-14.3)$ \\
Year of Media Story & 10999 & 11300 & $2.70(0-5.47)$ \\
\hline
\end{tabular}

Table 5. Female helpline contacts in the two weeks before and after each media event, comparison to previous years: Total number and rate ratio

\begin{tabular}{lllll}
\hline Media story & $\begin{array}{l}\text { Total contacts } \\
\text { before }\end{array}$ & $\begin{array}{l}\text { Total contacts } \\
\text { after }\end{array}$ & $\begin{array}{l}\text { Rate Ratio (95\% } \\
\text { CI) }\end{array}$ & p value \\
\hline Ian Thorpe television interview & & & 0 \\
Year 4 & 7109 & 6900 & $-2.94(-6.61-0.3)$ & \\
Year 3 & 8059 & 8247 & $2.30(-0.8-5.5)$ & \\
Year 2 & 8908 & 8919 & $0.10(-2.8-3)$ & \\
Year 1 & 8935 & 8666 & $-3.01(-5.8--0.1)$ & \\
Year of Media Story & 10668 & 11697 & $9.60(6.8-12.6)$ & \\
\hline David Smiedt & & & & \\
Year 4 & 2269 & 2446 & $7.80(2-14)$ & \\
Year 3 & 2996 & $-3.14(-7.9-1.85)$ & \\
Year 2 & 3093 & 3045 & $4.46)$ & \\
\hline
\end{tabular}




\begin{tabular}{|c|c|c|c|c|}
\hline Year 1 & 2660 & 2975 & $11.80(6-17.8)$ & \\
\hline Year of Media Story & 3788 & 3845 & $1.50(-2.95-6.2)$ & \\
\hline \multirow[t]{2}{*}{ John Cantwell } & & & & 0.0052 \\
\hline & & & $-6.21(-9.12--$ & \\
\hline Year 4 & 7983 & 7487 & $3.2)$ & \\
\hline Year 3 & 9595 & 9282 & $-3.30(-6--0.5)$ & \\
\hline Year 2 & 9834 & 9189 & $-6.60(-9.2--3.9)$ & \\
\hline \multirow[t]{2}{*}{ Year 1} & 9523 & 9291 & $-2.40(-5.2-0.4)$ & \\
\hline & & & $-8.61(-10.91-$ & \\
\hline Year of Media Story & 12359 & 11295 & $6.25)$ & \\
\hline \multirow[t]{2}{*}{ Edward Fernon } & & & & 0.0067 \\
\hline & & & $-0.21(-3.34-$ & \\
\hline Year 4 & 7577 & 7561 & $3.02)$ & \\
\hline \multirow[t]{2}{*}{ Year 3} & 9565 & 9743 & $1.86(-0.97-4.78)$ & \\
\hline & & & $1.00(-1.85-$ & \\
\hline Year 2 & 9335 & 9428 & 3.93) & \\
\hline Year 1 & 9583 & 9107 & $-5.00(-8--2.2)$ & \\
\hline Year of Media Story & 11695 & 11484 & $-1.80(-4.3-0.76)$ & \\
\hline \multicolumn{5}{|l|}{ Ian Thorpe book } \\
\hline release & & & & 0.6108 \\
\hline
\end{tabular}




\begin{tabular}{|c|c|c|c|c|}
\hline & & & $4.19(-0.93-$ & \\
\hline Year 4 & 7455 & 7767 & $7.55)$ & \\
\hline Year 3 & 9649 & 10159 & $5.29(2.39-8.26)$ & \\
\hline Year 2 & 9393 & 10014 & $6.61(3.65-9.66)$ & \\
\hline Year 1 & 9089 & 9584 & $5.45(2.46-8.52)$ & \\
\hline Year of Media Story & 11381 & 11778 & $3.49(0.86-6.19)$ & \\
\hline Matthew Mitcham & & & & 0 \\
\hline Year 4 & 8008 & 8343 & $4.18(1.04-7.43)$ & \\
\hline Year 3 & 10310 & 10372 & $0.60(-2.1-3.38)$ & \\
\hline & & & $-1.46(-4.19-$ & \\
\hline Year 2 & 9842 & 9698 & 1.34) & \\
\hline & & & $-22.12(-24.4--$ & \\
\hline Year 1 & 9914 & 7721 & 19.77) & \\
\hline Year of Media Story & 11992 & 12595 & $5.03(2.43-7.69)$ & \\
\hline \multirow[t]{2}{*}{ Ruby Rose } & & & & 0 \\
\hline & & & $-3.90(-6.81--$ & \\
\hline \multirow[t]{2}{*}{ Year 4} & 8309 & 7985 & $0.9)$ & \\
\hline & & & $-11.38(-13.8--$ & \\
\hline Year 3 & 10619 & 9411 & 8.89) & \\
\hline
\end{tabular}




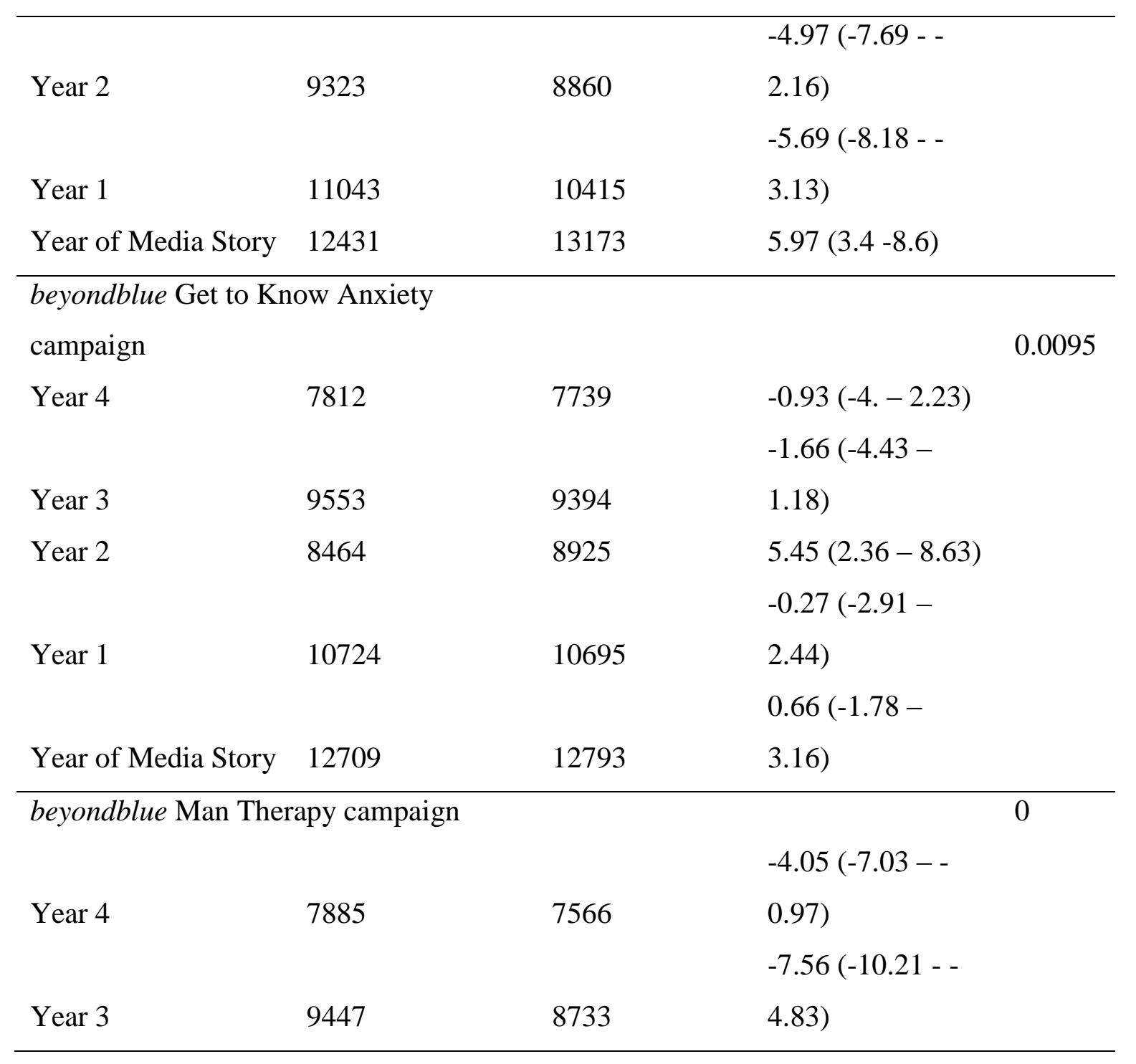




\begin{tabular}{|c|c|c|c|}
\hline & & & $-1.63(-4.46-$ \\
\hline Year 2 & 9073 & 8925 & $1.29)$ \\
\hline Year 1 & 10458 & 10541 & $0.79(-1.9-3.56)$ \\
\hline Year of Media Story & 13172 & 13533 & $2.74(0.3-5.23)$ \\
\hline \multirow[t]{2}{*}{ Harry O'Brien } & & & \\
\hline & & & $2.99(-0.12-$ \\
\hline \multirow[t]{2}{*}{ Year 4} & 8068 & 8309 & $6.19)$ \\
\hline & & & $0.48(-2.42-$ \\
\hline Year 3 & 8903 & 8946 & $3.47)$ \\
\hline Year 2 & 8873 & 8754 & $-1.34(-4.21-1.6)$ \\
\hline \multirow[t]{2}{*}{ Year 1} & 10658 & 11676 & $9.55(6.7-12.47)$ \\
\hline & & & $1.80(-0.61-$ \\
\hline Year of Media Story & 13202 & 13440 & $4.28)$ \\
\hline
\end{tabular}

Table 6. Overall helpline contacts in the two weeks before and after each media event, comparison to previous years: Total number and rate ratio

\begin{tabular}{lllll}
\hline Media story & Total contacts before & $\begin{array}{l}\text { Total contacts } \\
\text { after }\end{array}$ & Rate Ratio (95\% CI) & p value \\
\hline $\begin{array}{l}\text { Ian Thorpe television interview } \\
\text { Year 4 }\end{array}$ & 14300 & 13967 & $-2.30(-17.7-16)$ & 0.78 \\
\hline
\end{tabular}




\begin{tabular}{|c|c|c|c|c|}
\hline Year 3 & 17547 & 18175 & $4.00(-12-24)$ & \\
\hline Year 2 & 19059 & 18927 & $-1.10(-16.62-17)$ & \\
\hline Year 1 & 19074 & 18755 & $-2.00(-17.03-17)$ & \\
\hline Year of Media Story & 22288 & 24818 & $12.00(-5.6-33)$ & \\
\hline David Smiedt & & & & 0.24 \\
\hline Year 4 & 4831 & 4909 & $0.00(-14.7-17)$ & \\
\hline Year 3 & 6661 & 5893 & $-14.20(-26.7-0.5)$ & \\
\hline Year 2 & 6155 & 6057 & $-2.10(-16.4-14.7)$ & \\
\hline Year 1 & 5657 & 6070 & $6.00(-9.5-24)$ & \\
\hline Year of Media Story & 7245 & 7776 & $9.60(-6.32-28.3)$ & \\
\hline John Cantwell & & & & 0.6959 \\
\hline Year 4 & 16246 & 15642 & $-2.80(-12.5-7.9)$ & \\
\hline Year 3 & 20220 & 20176 & $0.57(-9.35-11.58)$ & \\
\hline Year 2 & 20414 & 19104 & $-6.52(-15.75-3.7)$ & \\
\hline Year 1 & 21037 & 20725 & $-1.00(-10.7-9.9)$ & \\
\hline Year Media Story & 26166 & 23928 & $-8.50(-17.46-1.5)$ & \\
\hline Edward Fernon & & & & 0.8664 \\
\hline Year 4 & 15503 & 16255 & $6.92(-4.82-20.1)$ & \\
\hline Year 3 & 20678 & 20972 & $1.50(-9.6-14)$ & \\
\hline Year 2 & 19454 & 19598 & $0.60(-10.4-12.99)$ & \\
\hline
\end{tabular}




\begin{tabular}{|c|c|c|c|c|}
\hline Year 1 & 20822 & 20710 & $0.70(-10.31-13.07)$ & \\
\hline Year of Media Story & 24988 & 24436 & $-2.50(-13.13-9.46)$ & \\
\hline Ian Thorpe book release & & & & 0.988 \\
\hline Year 4 & 16005 & 16499 & $2.75(-9.73-16.95)$ & \\
\hline Year 3 & 20866 & 21853 & $4.70(-7.95-19)$ & \\
\hline Year 2 & 19511 & 20599 & $5.00(-7.44-19.8)$ & \\
\hline Year 1 & 20472 & 20809 & $0.48(-12-14)$ & \\
\hline Year of Media Story & 24120 & 25139 & $4.00(-8.4-18.5)$ & \\
\hline Matthew Mitcham & & & & 0.012 \\
\hline Year 4 & 17017 & 17875 & $5.39(-7-19)$ & \\
\hline Year 3 & 21857 & 22176 & $1.70(-10.14-15)$ & \\
\hline Year 2 & 20296 & 20426 & $1.25(-11-15)$ & \\
\hline Year 1 & 22344 & 18020 & $1.25(-10.55-14.6)$ & \\
\hline Year of Media Story & 25444 & 26894 & $-19.22(-28.64--8.6)$ & \\
\hline Ruby Rose & & & & 0.8399 \\
\hline Year 4 & 17400 & 16896 & $-2.90(-14.8-10.8)$ & \\
\hline Year 3 & 21214 & 19335 & $-8.54(-19.8-4)$ & \\
\hline Year 2 & 19635 & 18733 & $-4.40(-16.2-8.99)$ & \\
\hline Year 1 & 23011 & 21471 & $-6.67(-18.12-6)$ & \\
\hline Year of Media Story & 28679 & 29351 & $1.00(-11-15.6)$ & \\
\hline
\end{tabular}




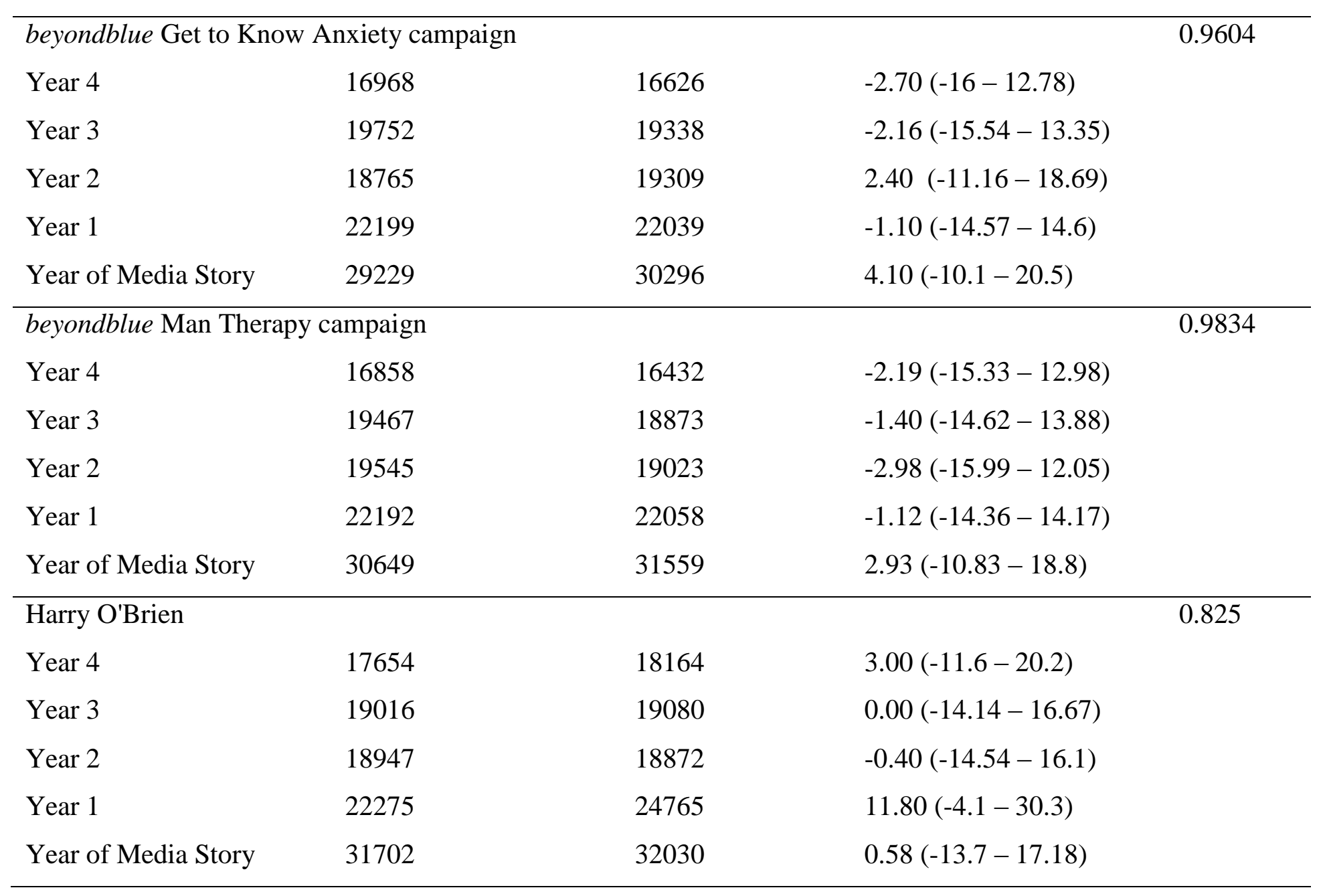


